weeks to prepare for the presentation, students had a more gradual introduction to the presentation. And it was early in the semester when they had more time to devote to teamwork instead of late in the semester when both students and faculty have frayed nerves and time challenges.

By conducting research early in the semester for the oral presentation, students were ready to use their research techniques in more depth when preparing for a written report on a different topic.

Perhaps you might wish to revisit the structure of your oral presentation and decide if it is the best opportunity for your students or if changes would enhance your results.

Address correspondence to Marsha L. Bayless, Department of Business, Stephen F. Austin

State University, Nacogdoches TX 75962; e-mail: mbayless@sfasu.edu.

\title{
BREAKING BAD HABITS: TEACHING EFFECTIVE POWERPOINT USE TO WORKING GRADUATE STUDENTS
}

Gretchen N. Vik

San Diego State University

ONE INTERESTING aspect of teaching students to use PowerPoint and similar graphics packages effectively is that graduate students who are already in the workforce often have bad presentation habits that they need to break. In my experience teaching regulatory affairs and biotech professionals, Navy officers near the end of their active duty careers, and assorted engineers and county and city administrators, their bad habits include the usual suspects:

- Too many words on a slide, often almost a script

- Backgrounds that are too busy or inappropriate

- Too much animation, sound, and other bells and whistles

- Too many slides for actual speaker time (Why not just use a handout?)

- Overcomplicated graphics, especially military ones

- Lack of presentation structure

I will discuss ways of breaking these bad habits, but a larger problem in many classroom presentations is the lack of a point or reason for presenting; too many people just present a mass of information. We use 
the "So?" test. Does your audience understand why they are getting all this information? What action are they supposed to take once they have absorbed all the information and analysis?

\section{Practical Solutions-Use Storyboards}

Using storyboards is one way to keep students from putting a whole written report on their slides. Storyboards also focus the presentation planning on main points, analysis, and answers rather than on mere information. I tell students to think of their main point for this section of the presentation, then several things they want to say about that point, then the transition to their next point. They need to consider ways of showing these ideas rather than just listing or telling them. Storyboards are also effective in planning a presentation that has no accompanying written report.

\section{Practical Solutions-Presentation Structure}

A basic structure for a presentation ought to include a blank opening and closing slide to mask the innards of the PowerPoint program, a title slide, an outline slide (not called Agenda or Outline, those stultifying words), detail slides as needed, as well as a Questions? slide and a Thank you slide at the end. Bailey (2002) recommends a moving blueprint slide that speakers can use repeatedly as they cover each point. It reminds the listeners where they are in the plan of the presentation. Bailey compares such a slide to the headings in a written report-both act as signposts to the audience about organization and plan (pp. 161168). Although a blueprint slide is less important in very short talks because it may be too repetitious for an audience that has not had time to forget a presenter's few points, it definitely provides structure in a longer presentation.

\section{Practical Solutions-Submit Presentation Slides for Review}

Problems of busy slides, overly wordy slides, too many slides for the allotted time, and lack of presentation structure can usually be headed off by requiring students to submit the presentation slides a week before the presentation for instructor review and comments. For many years, I assigned presentations and discussed expectations but never looked at the slides until the actual presentations. Students do better when you look at the slides ahead of time, when you get a copy of them at the beginning of the presentation (six per page is fine), and when 
you include the slides as a grading point in your grading rubric for the assignment.

\section{Practical Solutions-Use the Slides}

As Zelazny (2000) points out in his presentations book (a great followup to the long-standing Say It With Charts [2001]), a danger of PowerPoint is that it can cause the audience to focus on the visuals rather than on the speaker. Many of my students speak with expression, have the right pauses and gestures, but seem entirely separate from the slides they have so carefully prepared. Putting points on the grading rubric for slide use helps: Use slides (point at, move back by the screen, turn to the slides, refer to the slides). With our smart classrooms, students are not as likely to use the computer screen as their script as they did in times past, but they still tend to ignore the slides unless reminded to use them.

Transitions between slides can be a problem sometimes because students are not yet familiar with the mechanics of changing slides, because all the flying in and out and animation takes too much time, or because the audience is not prepared. Zelazny (2000) recommends transitioning before changing visuals-finish discussing a slide, make the oral transition to the next idea, and then change the slide (pp. 114$115)$.

\section{Practical Solutions-Have a Message}

Most of my graduate students have a lot to say but often do not seem to have a reason for speaking. Zelazny (2000) has a Draconian way of planning a presentation: imagine that your time is cut to 30 seconds to a minute. What would you say? That is your message. He describes it as a bumper sticker mentality for capturing the reader's interest (pp. 3637). Assume that the audience has asked a question. A presentation should answer the question, showing reasons for the answer. For most presentations, students should begin with the conclusion and then explain how they arrived at it rather than explaining chronologically (so slow) or deductively (so mysterious).

\section{Media or Message?}

My students seem to be past the stage of thinking PowerPoint is the whole presentation, as often happened in the early years of the program. (Remember The Wall Street Journal article on military overuse of PowerPoint shows?) In-class practice helps them learn the strengths 
and the weaknesses of this software as they improve their presentation skills.

\section{REFERENCES}

Bailey, E. P. (2002). Writing and speaking at work: A practical guide for business communication (2nd ed.). Upper Saddle River, NJ: Pearson Education.

Zelazny, G. (2000). Say it with presentations: How to design and deliver successful business presentations. New York: McGraw-Hill.

Zelazny, G. (2001). Say it with charts: The executive's guide to visual communication. New York: McGraw-Hill.

Address correspondence to Gretchen N. Vik, Information and Decision Systems Department, College of Business Administration, San Diego State University, San Diego CA 921828234; e-mail: gvik@mail.sdsu.edu.

\section{WORKING THROUGH POWERPOINT: A GLOBAL PRISM FOR LOCAL REFLECTIONS}

Michael Connor

Irene F. H. Wong

Nanyang Technological University

STUDENT PRESENTATIONS have assumed such prominence at the Nanyang Business School (NBS), Singapore, that business communication academics have begun conducting workshops on presentations for other faculty members. In addition to guidance on assessing student presentations, we offer theoretical and practical perspectives on PowerPoint, which most of our colleagues have been using in business and education for years. However, in developing useful approaches to these sessions and from discussions during them, we realized that we have been addressing larger issues that PowerPoint reflects prismatically. We now think that we may have found, in PowerPoint's problematic centrality to business and education everywhere, certain avenues for addressing these global communication concerns within our local pedagogic context.

Our workshop participants have the usual anxieties about PowerPoint. Its use demands the simplification and reduction of content, and it can cloud reasoning. It can promote style over substance. 
Copyright of Business Communication Quarterly is the property of Association for Business Communication and its content may not be copied or emailed to multiple sites or posted to a listserv without the copyright holder's express written permission. However, users may print, download, or email articles for individual use. 